\title{
Protecting Fundamental Rights within the European Union
}

Submitted 30/05/20, $1^{\text {st }}$ revision $12 / 06 / 20$, $2^{\text {nd }}$ revision 09/07/20, accepted 30/07/20

\author{
Oksana V. Shcherbanyuk ${ }^{1}$, Oksana V. Kurylina ${ }^{2}$, Natalia A. Serdiuk ${ }^{3}$, Oleh \\ V. Ilnytskyi ${ }^{4}$, Serhii V. Bashlai ${ }^{5}$, Petro A. Trachuk ${ }^{6}$
}

\begin{abstract}
:
Purpose: The purpose of this article is to study the basis of a multidisciplinary approach and a comparative method of protection of basic economic rights in the European Union in order to determine the degree of their protection and implementation and to determine the model of state intervention in the economy.

Design/Methodology/Approach: The study based on comparative analysis of state intervention models in the implementation of economic freedom. Doctrinal legal analysis is based on a dual method: first, descriptive and analytical, which explains all points of view, and second, a neutral and critical assessment of certain academic debates and legal considerations.
\end{abstract}

Findings: The research findings demonstrate that the characteristic features of the protection of economic rights of individuals and legal entities in the EU countries are analyzed. The need to study the case law of the EU Court is identified and justified. Based on the analysis, the article suggests paying attention to the obligations of business to respect human rights. It is concluded that it is necessary to develop the state's obligations in the field of economic and social human rights, their protection and promotion. At the same time, the state's obligations to protect economic human rights require that the state prevent violations of economic human rights by third parties.

Practical Implications: This research raises awareness of the instrument to strengthen the rule of law, helping to promote judicial reform and the rule of law that has a significant impact on investment decisions and business engagement. Policy makers should devote

\footnotetext{
${ }^{1}$ Associate Professor, Yuriy Fedkovych Chernivtsi National University, Chernivtsi, 58012, Ukraine, E-mail: oksanashcherbanyuk7@gmail.com

${ }^{2}$ Associate Professor, National Defence University of Ukraine named after Ivan

Cherniakhovskyi, Kyiv, 03063, Ukraine, E-mail: ks-kr@ukr.net

${ }^{3}$ Associate Professor, Kyiv National Linguistic University, Kyiv, 03150, Ukraine,

E-mail: serdyuk_natalia@ukr.net

${ }^{4}$ Associate Professor, Ivan Franko National University of Lviv, Lviv, 79000, Ukraine,

E-mail: oleh.ilnytskyy@lnu.edu.ua

${ }^{5}$ Associate Professor, Sumy National Agrarian University, Sumy, 40030, Ukraine.

E-mail: bash_serg@ukr.net

${ }^{6}$ Professor, Uzhhorod National University, Uzhhorod, 61080, Ukraine,

E-mail: Trachuk.p@gmail.com
} 
special attention to independence, quality and efficiency, as the most important elements of an effective justice system.

Originality/Value: The study highlights that economic construction of the EU, created by the case law of the Court of Justice of the EU, was aimed at developing a common market built on the prohibition of any restrictions or distortions of free competition.

Keywords: Social and economic rights, protection of economic rights, common market, free competition; economic model, Court of justice of the European Union.

JEL Codes: D7, D73, D78, C5, C54.

Paper Type: Research paper.

\section{Introduction}

The article originally explores the issue of protection of basic economic rights in the European Union. The relevance of this problem is due to the fact that the protection of economic rights of individuals (individuals and legal entities) is extremely important for the EU, since socio-economic human rights are enshrined in the provisions of the European social Charter (revised), the European Convention for the protection of human and civil rights and fundamental freedoms and the Charter on basic social rights of EU workers.

Today, the EU is already introducing the substantive rules of the Convention and the case law that is being formed by the European Court of justice into its domestic law. At the same time, the requirement of uniformity of understanding of social and legal norms is explicitly stated in the articles of the Charter (Sokolov, 2009). The protection of fundamental economic rights is one of the most urgent issues that needs to be studied, taking into consideration the development of creative economy and strengthening of innovation potential of EU countries (Kubiv et al., 2020), internationalization and expansion of cooperation between countries and regions (Arabadzhyiev et al., 2020), as well as issues of ensuring sustainable development within the conditions of the fourth industrial revolution (Bashtannyk et al., 2020).

The obligations imposed by economic rights should be treated in the same way as civil and political rights. This may include granting freedoms, imposing obligations on the state in relation to third parties, and imposing obligations on the state to take measures or achieve a certain result. Ensuring economic rights helps to improve the consequences of the economic crisis. Widespread and prolonged unemployment leads to severe consequences for both the national economy and the demographic indicators of the unemployed. At the same time, judicial protection of human rights is crucial. A right without a remedy raises the question whether it is a right at all. This means that judicial protection is the only, if not the best, way to protect 
economic, social and cultural rights. This determines the relevance of the chosen topic.

The research aim of the present study is to investigate the basis of a multidisciplinary approach and a comparative method of protection of basic economic rights in the European Union in order to determine the degree of their protection and implementation and to determine the model of state intervention in the economy.

\section{Literature Review}

Personal studies of the protection of fundamental economic rights in the EU have been the subject of research (Whelan and Donnelly, 2007), but the emergence of new positions of the Court of Justice on the protection of economic rights and freedoms require new research. Special attention should be paid to the observance of human rights by business, because business addresses the requirements to respect human rights in carrying out economic activities both within national borders and beyond. It should be noted that in the last decade, the issues of business obligations in the field of human rights have become particularly relevant in the last decade.

Discussions on this issue aimed at developing appropriate recommendations, a roadmap that would effectively implement the idea that not only the state, but also business has obligations to respect, and ensure human rights. Over the past decade, new theories of (constitutional) pluralism have emerged. This theory is presented by various authors who are trying to build a new horizontal relationship between legal acts and the Supreme jurisdictions of Europe (Ramona, 2016). In recent years, there have been significant changes in the European Union. The reasons for changes are external (globalization, introduction of a service-based economy, market instability and unexpected shocks in the labor market, moving away from cyclical structural risk) (Mendez-Pinedo, 2020) and internal (declining birth rate, aging population, new family forms) (Clasen and Clegg, 2006).

Holovatyi (2015) analyzed the conceptual principles and social interaction in the context of the formation and functioning of states from an economic point of view and revealed the EU experience in planning socio-economic development of territories. Akimov et al. (2020) thoroughly analyzed innovative forms of employment in the conditions of market transformation. Akimova et al. (2020) have studied and formed the organizational and financial basis for stimulating the development of regional development.

However, the issue of protection of basic economic rights in the EU countries requires the following research, because it is particularly significant that individuals have begun to play an active role in the implementation of EU law within national legal systems. 
The EU intends to continue to expand trade and economic relations with China, but at the same time seeks more reliable guarantees of trade with China to adhere to fair and transparent trade rules and to fulfill bilateral obligations within the World Trade Organization (WTO). The authors define the need for gradual investment liberalization and removal of restrictions for investors in each other's markets. This will provide a simpler and safer legal framework for investors on both sides, providing them with reliable protection and their investments (Birimkulova et al., 2019).

Imamov (2019) identified the problems of interconnection, mutual subordination and mutual consistency between the concepts of "monetary regulation" and "monetary policy". To distinguish the theoretical and applied aspects of the application of these concepts in the article, the article describes the essence of "economic regulation" and "economic policy" in a general context without reference to the monetary sphere.

Gonzalez-Fuster (2014) emphasizes that a careful analysis of the case law of the Court of Justice on the right to protection of personal data and privacy reveals not only inconsistencies and weaknesses, but in general clearly distinguishing the contours of each right, their essence. The main negative consequence of this contradictory judicial practice is the lack of reliable authority on the right to personal data protection more than ten years after its introduction in the catalog of fundamental EU rights.

There is more in balancing basic social rights and economic freedoms than in comparing different methods of judicial decisions only by European courts. After all, the EU is a politically possible social economic model. All standards are reduced to the basic principle that "labor is not a commodity". Based on the analysis of the case law of the European Court of Human Rights, Veldman (2013) points to the conflict between fundamental social rights and economic freedoms. The legal order of the EU, compared to the purely human rights-based order in the Convention, is due to the fact that the specific interests of workers are partially harmonized with regard to the internal market through the EU directive.

The researcher analyzes the case of the Vikings, in which the Court recognized the fundamental nature of the right to collective action, referring to ILO Convention No.87 on Freedom of Association and the Right to Organize and to Article 28 of the EU Charter. In the Court's view, the exercise of a fundamental right must be consistent with the requirements of the Treaty. The community has not only an economic but also a social purpose and the interests of social policy must be balanced with the rules of free movement. The aim is that "equalization" means that appropriate collective actions must meet the justification for restricting free movement, including the proportionality test. However, the court ruled that the right to collective action to protect workers - is, in principle, a legitimate interest, which may justify the restriction of freedom of collective action. 
The above review of the literature indicates a constant increased attention of researchers to the protection of basic economic and related social rights in the EU countries.

\section{Research Methodology}

The main methodological tools for considering the protection of basic economic rights in the EU countries are an interdisciplinary approach, due to the problem and the need to understand the nature of economic processes; legal pluralism, which involves operating various models of state intervention in the economy and justifying the legitimacy of intervention; balancing, since economic issues are closely related to the dilemma of access to resources and values in law. Comparative analysis of models of state intervention in the implementation of economic freedoms through the prism of proportionality has shown that the application of specific measures by the state depends on a certain structure of the economy, the degree of its differentiation, its openness and the provision of economic freedoms. Doctrinal legal analysis is based on a dual method: first, descriptive and analytical, which explains all points of view, and second, a neutral and critical assessment of certain academic debates and legal considerations.

\section{Empirical Findings}

Regularization of economic processes refers to interference in the exercise of freedom, which may be justified by access to or preservation of certain benefits, in particular by ensuring the sustainable development of society. The idea of General regulation of economic processes does not meet the requirements of legal certainty, predictability of rules and prohibition of arbitrariness. In European practice, criteria for state intervention have been developed through the interpretation of the constructions "provided by law" and "necessary in a democratic society". Within the European paradigm, there are many serious problems, for example, the possibility of judicial review of economic and social rights as fundamental is not equally regulated. The public authorities should implement a policy of fair and efficient redistribution of national resources, avoiding irregularities.

There is a list of general objectives of the EU in the EU Treaty with the system of values, among which an important place is occupied by economic, social, scientific, technical and cultural goals. They relate to the creation and functioning of the single economic space (the EU's "internal market") and the implementation within it of policies and measures to develop the economic, social and territorial cohesion and solidarity of the Member States. The construction of an economic and monetary union within the EU should be singled out, which is due to the development of integration in both economic and other spheres of life. The EU also has the main goals of foreign economic activity, namely the establishment and promotion of the values and interests of the EU in relations with the world, the protection of the interests of its citizens, the promotion of peace, security and more. Modern human 
rights law imposes three levels of obligations on the state: the obligation to respect, protect and ensure.

Obligations to respect require the state to refrain from any measures that may deprive individuals of their rights or exercise their own rights. Commitments to respect for human rights include non-interference in their implementation. The obligation to protect requires the state to prevent human rights violations by third parties. Obligations to provide stipulate that states must take measures (legislative, judicial, administrative, etc.) to provide individuals with opportunities to meet their basic needs that cannot be met by their personal efforts. This is a key commitment of the state to economic and social rights.

A separate topical issue is the protection of economic human rights from violations by business and multinational companies, the protection of intellectual property, the protection of freedom of enterprise and the right to work. Given the current trends of economic processes, there are three bases of business support, in particular: compliance as a culture of business integrity and fair conduct in the market, due diligence, ie., reliability of financial, tax and statistical reporting, correctness of documents, their compliance with legislation and forensic - detection activities economic risks, analysis and settlement of financial and economic disputes.

Infringement proceedings are an important tool for sanctioning fundamental rights in the EU. They can be initiated in cases where national law does not comply with EU law and the fundamental rights protected by it, in individual and specific cases (whereas Article 7 applies to situations outside the scope of EU law and where fundamental rights are systematically and permanently violated).

Today, it is undeniable that business makes a positive and profound contribution to the realization of human rights, as companies provide opportunities for employment and skills development, which in turn contributes to the realization of the right to work and fair remuneration and a decent standard of living. However, enterprises can harm human rights, in particular by using forced labor, discriminating against employees, interfering with the privacy of employees and/or consumers, or polluting the environment (Eide, 1989).

Industries that make extensive use of intellectual property rights, such as patents, trademarks, industrial designs and copyrights, generate $45 \%$ of GDP (6.6 trillion euro) annually in the EU and account for 63 million jobs (29\% of all jobs). Another 21 million people are employed in industries that supply these industries with goods and services. These are the results of a joint report published by the European Patent Office (EPO) and the European Union Intellectual Property Office (EUIPO), which analyzes the importance of intellectual property rights for the EU economy between 2014 and 2016 (Figure 1). 
Figure 1. The value of intellectual property rights for the EU economy between 2014 and 2016. IPR-intensive industries: $€ 6,6$ trillion of value added or 45\% of EU GDP

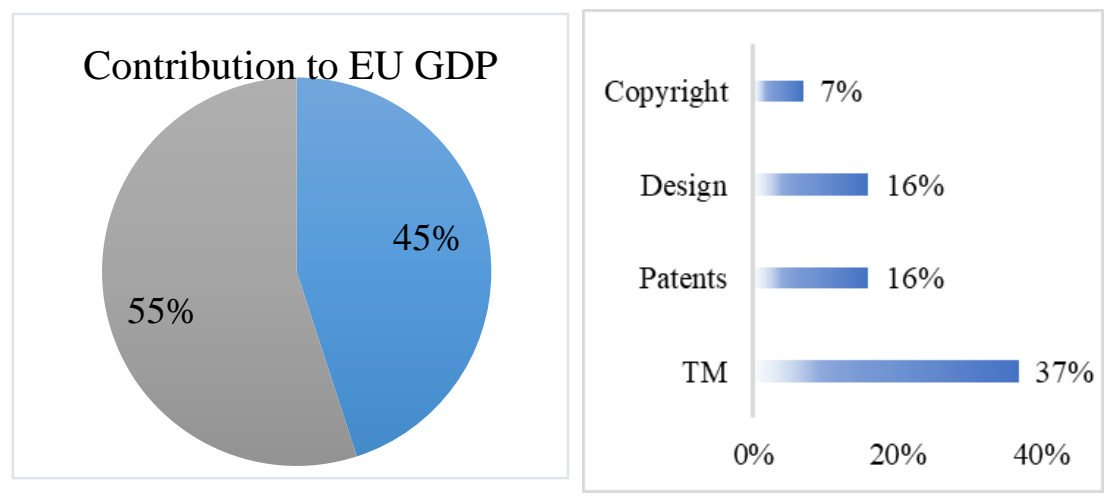

Source: European Patent Office (2019)

During the reporting period, employment in IPR-related industries increased by 1.3 million jobs compared to 2011-13, while total employment in the EU decreased slightly. Value added per worker in these industries is higher than in the rest of the economy. Accordingly, intensively protected IPR industries pay significantly higher wages: on average $47 \%$ more than other sectors, with this figure rising to $72 \%$ for patent-intensive industries (Figure 2).

Figure 2. The importance of intellectual property rights for employment in the EU between 2011 and 2013. IPR-intensive industries: 84 million jobs or 39\% of EU employment

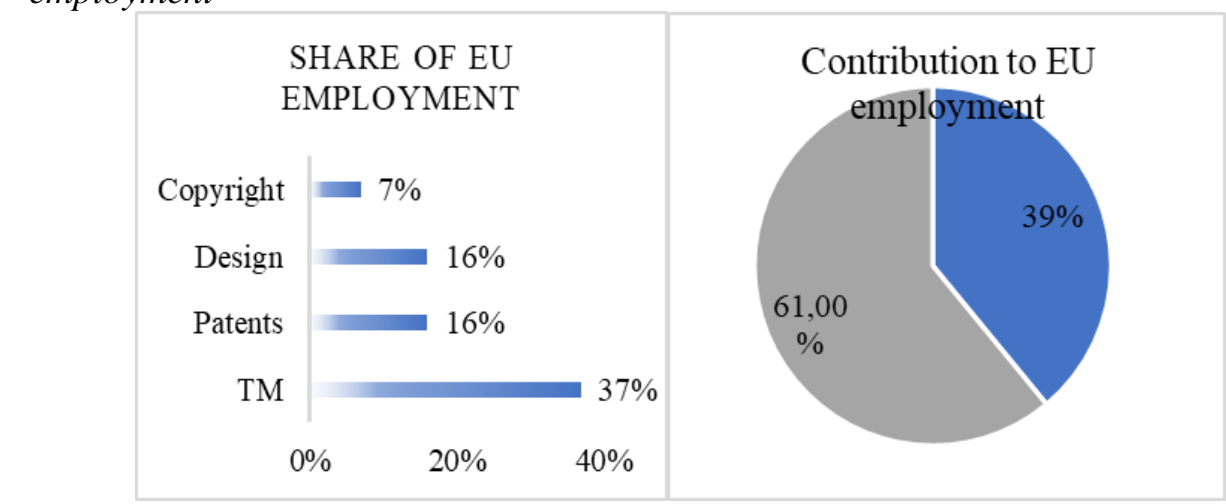

Source: European Patent Office (2019)

This report is the third in a series that tracks the contribution of industries that use above-average trademarks, patents, copyrights, geographical indications and plant diversity rights in economic growth and employment in the EU (Figure 3). 
Figure 3. The The contribution of industries to EU economic growth and employment

\begin{tabular}{|c|c|c|c|}
\hline \\
\hline 1000,00 & & 801,00 & 934,00 \\
\hline 800,00 & 54400 & & \\
\hline 600,00 & 344,00 & & \\
\hline 400,00 & & & \\
\hline \multicolumn{4}{|l|}{200,00} \\
\hline & $\begin{array}{l}\text { Non-IPR intensive } \\
\text { industries }\end{array}$ & IPR-intensive industries & $\begin{array}{l}\text { Patent-intensive } \\
\text { industries }\end{array}$ \\
\hline
\end{tabular}

Source: European Patent Office (2019)

The report says that patent-intensive industries employ about 24 million people and generate $16 \%$ of total EU GDP, as well as technology-specific areas. For example, in the field of climate change mitigation technologies (CCMT), for example, patentintensive industries accounted for $2.5 \%$ of employment and $4.7 \%$ of GDP during the period under review. The economic weight of the CCMT is expected to increase as countries work to achieve the goals set by the Paris Agreement. European firms already play a leading role in this technology sector; Almost $10 \%$ of all EU patent applications for EU applicants in recent years relate to CCMT (Figure 4).

Figure 4. The Intensively protected IPR in the field of foreign trade in EU goods and services

IPR-intensive industries in EU external trade in goods
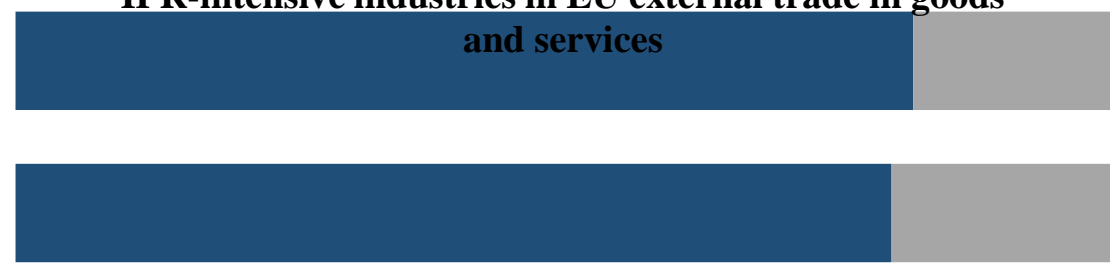

- Trade surplus;

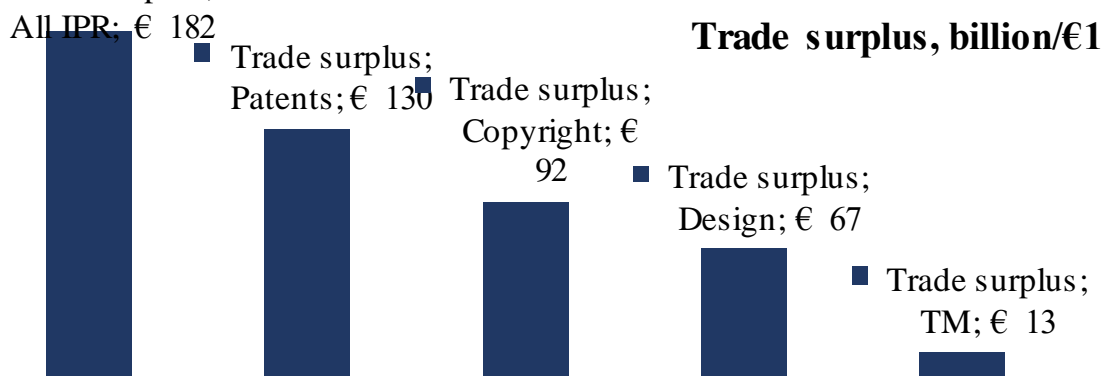

Source: European Patent Office (2019). 
Intensive intellectual property sectors also account for most of the EU's trade in goods and services with other regions of the world $(81 \%)$. The EU as a whole in 2016 had a total trade balance in IPR-related industries of approximately 182 billion euro, offsetting a small deficit in non-IPR-intensive trade.

The report also examines the patent-intensive industry, which makes a major contribution to the Fourth Industrial Revolution (4IR) technology and the digital transformation in the EU. He finds that these 4IR-intensive industries account for $1.9 \%$ of total employment in the EU and $3.9 \%$ of GDP in 2014-16, both of which are growing compared to 2011-13. In terms of wages, 4IR-intensive industries pay more than twice the average in non-intellectual property industries and are $39 \%$ higher than wages in all IPR industries.

The EU has a rich design tradition and is a world leader in industrial design. Industrial intensive industries have a strong economic impact within the EU-28. In total, design-using industries account for 30.7 million direct jobs and account for $16.2 \%$ of total EU GDP. Exports in this sector led to a trade balance of over 66 billion euros in 2016.

Trademark registration often indicates future business success, the creation of a company brand and emphasizing its differences in the market. Trademark-intensive industries account for $37 \%$ of EU GDP and support 46.7 million jobs. These industries also pay wages that are $48 \%$ higher than industries that do not use intellectual property rights. However, the protection of these civil rights needs important attention.

Protecting individuals from non-compliance by Member States with their obligations under EU law through national courts rather than through supranational institutions can be seen as a very effective mechanism in the light of the EU Court of Justice's concept of private liability for infringements and redress. losses. The European Court of Justice has perfectly developed this concept on the basis of a fundamental decision in the Francovich case (Judgment of the Court, 1991).

The mechanism of protection of economic rights includes both judicial and extrajudicial mechanisms. Extrajudicial mechanisms are the right to petition any EU body through a petitions committee. Judicial protection of economic rights involves recourse to both the national court and the Court of Justice. In this case, an individual can protect their rights if they are violated by an EU institution (for example, the abolition of EU regulations). The Court of Justice has stated in BrasserieduPecheurvGermany that in order to determine the conditions under which a Member State may be liable for damage caused to individuals as a result of infringements of Community law, account must first be taken of the principles of Community law which form the basis of State liability, namely, the full effectiveness of the Community rules and the effective protection of the rights which they confer, 
and the obligation to cooperate imposed on the Member States by Article 5 of the Treaty (Lage and Brokelmann, 2004).

The court in Uniónde Pequeños Agricultoresv Council of the European Union stated that effective judicial protection is guaranteed not only by Art. 263 of the Treaty on the Functioning of the European Union, but also a set of articles, in particular Art. 267 by means of preliminary rulings. On 22 September 1966, the Council adopted Regulation No.136/66/EEC establishing a common organization of the market in oils and fats. In particular, these regulations established a common organization of olive oil markets, structured around a system of guaranteed prices and production aid.

Thus, the EU has created a flexible and effective mechanism for judicial protection of economic rights of individuals. The new EU directives allow victims to be protected by collective actors, including trade unions and NGOs.

The 2020 global crisis associated with the COVID-19 pandemic has increased attention to guaranteeing and protecting economic and social rights. The pandemic has exposed economic inequality, especially in countries with weak social protection systems, protection. Therefore, the problem of protection of economic rights is timely, and the judicial system must respond effectively.

Improving the independence, quality and efficiency of the judiciary is a wellestablished priority of structural reforms, which are encouraged in the EU through the European Semester. The European Semester cycle begins each year in November, when the European Commission presents its priorities for next year.

Between 2007 and 2020, more than 900 million euro is earmarked for improving the efficiency and quality of justice in the Member States, including: financing measures for the development and improvement of business processes in the courts and the implementation of case management systems or the development or modernization; human resource management processes; digitalization of court services and acquisition of information and communication technology (ICT) systems; training of judges, prosecutors, court employees, bailiffs, state notaries, lawyers and raising public awareness of their rights.

\section{Discussion and Conclusions}

The economy is a holistic system, the parameters of which are mutually agreed, develop on the basis of freedom and combine economic development within economic cycles (Schumpeter, 1961). As a fundamental constitutional principle, the "welfare state" performs three functions: a) allows government intervention and dirigisme (any kind of positive action) in the economic sphere, respectively, the regulation of the economy covers two sides - supply and demand: from wages and working conditions to profit and investment; b) obliges the public authorities to intervene in the function of the market in order to guarantee the realization of 
fundamental social rights, to maintain social security and to equalize or reduce excessive social inequality; c) prohibits the dismantling of the basic structures of the general welfare state or the radical curtailment of legally established social rights (Schumpeter, 1961).

In turn, the executive and legislature do not have the right to arbitrarily redistribute available public assets, but they are legally obliged to find a way to achieve social goals to guarantee their citizens a minimum level that allows the country's economic resources (Katrougalos, 1998).

The economic construction of the EU, created by the case law of the Court of Justice of the EU, was aimed at developing a common market built on the prohibition of any restrictions or distortions of free competition. And ensuring the fundamental "four freedoms": freedom of free movement of goods, capital, works and services. The EU was given regulatory powers only in the field of competition, and economic policy remained within the competence of the Member States, which were obliged to remove obstacles to international agreements and distortions of competition due to differences in national legislation. Initially, the Court of Justice, referring to the general principles of the national legal orders of the Member States, recognized some unwritten general legal principles, including the protection of property rights and freedom of trade and profession, as derivatives of economic freedom (InfoCuria, 2014).

The EU has gradually eliminated economic protectionism and established competition rules governing private economic activity and state intervention in market relations. Initially, the case law of the Court of Justice led to the development of an economic model that limited (national) public intervention in economic agreements within the EU, allowing for internal measures such as privatization and intervention, especially in the public service sector of general interest. These provisions have been developed in the decisions of the Court of Justice.

Independence, quality and efficiency, as the most important elements of an effective justice system, are crucial to upholding the rule of law and the values on which the EU is founded. Effective justice systems are important for the implementation of EU law. National courts act as EU courts in the application of EU law. For this reason, improving the efficiency of national justice systems is a priority of the European Semester, the EU's annual economic policy coordination cycle.

\section{References:}

Akimov, O., Karpa, M., Parkhomenko-Kutsevil, O., Kupriichuk,V., Omarov, A. 2020. Entrepreneurship education of the formationof the e-commerce managers professional qualities. Journal of Entrepreneurship Education, 23(S1), 57-58. 
Akimova, L., Khomiuk, N. Bezena, I., Lytvynchuk, L., Petroye, O. 2020. Planning of socioeconomic development of the territories (experience of European Union). International Journal of Management, 11(4), 638-646.

Arabadzhyiev, D.Y., Buryk, Z.M., Barshatska, H.Y., Huba, M.I., Shashyna, M.V. 2020. Establishing interterritorial cooperation of amalgamated territorial communities as a tool to increase their capacity. International Journal of Management, 11(5), 10361044.

Bashtannyk, V., Buryk, Z., Kokhan, M., Vlasenko, T., Skryl, V. 2020. Financial, economic and sustainable development of states within the conditions of industry 4.0. International Journal of Management, 11(4), 406-413.

Birimkulova, G., Zhylkybekuly, B., Tashemkhanova, R. 2019. Perspective directions of multilateral cooperation between the EU and the PRC in the context of stabilizing the global financial system. Journal of Advanced Research in Law and Economics, 9(8), 2551-2561.

Clasen, J., Clegg, D. 2006. Beyond activation: Reforming European unemployment protection systems in post-industrial labour markets. European Societies, 8(4), 527553.

Eide, A. 1989. The realization of social and economic rights and the minimum threshold approach. Human Rights Law Journal, 10(1-2), 35-51.

Judgment of the Court. 1991. Andrea Francovich and Danila Bonifaci and others v Italian Republic. Available at: https://eur-lex.europa.eu/resource.html?uri=cellar:7a76ea3fa919-475c-8cbe-29e0b260ebc4.0002.03/DOC_1\&format=PDF

European Patent Office. 2019. Intellectual property rights strongly benefit the European economy, EPO-EUIPO study finds. Available at: https://www.epo.org/newsevents/news/2019/20190925.html

Gonzalez-Fuster, G. 2014. Fighting for your right to what exactly-the convoluted case law of the EU court of justice on privacy and/or personal data protection. Birkbeck Law Review, 2(2), 263-288.

Holovatyi, M. 2015. The state and society: The conceptualfoundations and social interaction in the context of formation andfunctioning of states. Economic Annals-XXI, 9-10, 48.

Imamov, M. 2019. Currency circulation as a factor of state economic stability. Journal of Advanced Research in Law and Economics, 9(8), 2603-2614.

Katrougalos, G. 1998. Constitution, Law and Rights in the Welfare State. Institut for Samfundsvidenskab \& Erhvervsøkonomi, Athens, Greece.

Kubiv, S.I., Bobro, N.S., Lopushnyak, G.S., Lenher, Y.I., Kozhyna, A. 2020. Innovative potential in European countries: Analytical and legal aspects. International Journal of Economics and Business Administration, 8(2), 250-264.

Lage, S., Brokelmann, H. 2004. The liability of the Spanish state for breach of EC law: The landmark ruling of Spanish tribunal supremo in the Canal Satelite digital case. European Law Review, 29(4), 530-545.

Mendez-Pinedo, E. 2020. Constitutional pluralism and legal perspectivism in European Union law Abstract: During the past decade, new theories of (constitutional) pluralism have challenged the classic authority and primacy of, Juridical Tribune (Tribuna Juridica). Bucharest Academy of Economic Studies, Law Department, 10(1), 5-35.

InfoCuria. 2014. Opinion 2/13 of the Court (Full Court). Opinion pursuant to Article 218 (11) TFEU - Draft international agreement - Accession of the European Union to the European Convention for the Protection of Human Rights and Fundamental Freedoms 
- Compatibility of the draft agreement with the EU and FEU Treaties. Available at: http://curia.europa.eu/juris/liste.jsf?num=C-2/13

Ramona, E. 2016. Business and human rights: from soft law to hard law? Juridical Tribune, 6(2), 228-246.

Schumpeter, J.A. 1961. Theory of economic development. Research of profits, capital, credit, interest and economic cycle. OUP, New York, NY.

Sokolov, V. 2009. Socio-economic standards and human rights in the European Union at the present stage of its development. Viche, 18. Available at: http://veche.kiev.ua/journal/1638/

Veldman, A. 2013. The protection of the fundamental right to strike within the context of the European internal market: Implications of the forthcoming accession of the EU to the ECHR. Utrecht Law Review, 9(1), 104-117.

Whelan, D.J., Donnelly, J. 2007. The west, economic and social rights, and the global human rights regime: Setting the record straight. Human Rights Quarterly, 29(4), 908-949. 